\title{
Phytochemical Profiling and In Vitro Anticancer Activity of Purified Flavonoids of Andrographis glandulosa
}

\section{(ㅇ)(1) $\circledast$}

\section{Authors}

Neeraja Cherukupalli ${ }^{*}$, Sudarshana Reddy Bhumireddy2, 3*, Subrahmanya Sarma V Akella ${ }^{4}$, Aaysha Sataniya ${ }^{5}$, Prabhakar Sripadi², 3 , Venkateswara Rao Khareedu' ${ }^{1}$, Dashavantha Reddy Vudem ${ }^{1}$

\section{Affiliations}

1 Centre for Plant Molecular Biology, Osmania University, Hyderabad, India

2 National Centre for Mass Spectrometry, CSIR-Indian Institute of Chemical Technology, Hyderabad, Telangana, India

3 Academy of Scientific and Innovative Research, CSIR-Indian Institute of Chemical Technology, Hyderabad, Telangana, India

4 Centre for NMR and Structural Chemistry, CSIR-Indian Institute of Chemical Technology, Uppal Road, Tarnaka, Hyderabad, India

5 Chemical Biology Division, CSIR-Indian Institute of Chemical Technology, Uppal Road, Tarnaka, Hyderabad, India

* Contributed equally

Key words

Andrographis glandulosa, Acanthaceae, chemical profiling, LC-MS, NMR-spectroscopy, ESI-MS/MS, anticancer activity

received 15.11 .2016

revised 18.02 .2017

accepted 28.02.2017

Bibliography

DOI http://dx.doi.org/10.1055/s-0043-105274

Published online: 2017

Planta Med Int Open 2017; 4: e24-e34

(c) Georg Thieme Verlag KG Stuttgart · New York

ISSN 2509-9264

\author{
Correspondence \\ Prof. V. Dashavantha Reddy \\ Centre for Plant Molecular Biology \\ Osmania University \\ Hyderabad 500007 \\ India \\ Tel.: + 91/40/27098 087, Fax: +91/40/27096170 \\ vdreddycpmb@yahoo.com
}

\begin{abstract}
The genus Andrographis includes diverse species of medicinal importance. The present study for the first time unravels the chemical profiling and medicinal importance of an unexplored species, Andrographis glandulosa. LC-MS analysis of A. glandulosa methanolic extract disclosed it as a rich source of flavonoids, with 8 minor peaks and 2 major peaks ( $\mathrm{m} / \mathrm{z}$ 285.0749 and 283.0595). NMR and ESI-MS/MS analyses confirmed the major peaks as (R) 2',5-dihydroxy-7-methoxyflavanone and 2',5-dihydroxy-7-methoxyflavone. Purified compounds exhibited antiproliferative activity on 3 cancer cell lines (HeLa, MIA PaCa and U-87) with IC ${ }_{50} 39.81$ $46.21 \mu \mathrm{M}$ for flavanone, and $20.84-25.16 \mu \mathrm{M}$ for flavone. $\mathrm{IC}_{50}$ values of flavone are on a par with that of the positive control quercetin (21.78$26.82 \mu \mathrm{M})$. HeLa cells treated with $117 \mu \mathrm{M}$ flavanone showed a loss of MMP ( $~ 55 \%$ of cells) resulting in apoptosis ( $~ 51 \%$ of cells). Treatment with $80 \mu \mathrm{M}$ flavone caused a loss of MMP ( $~ 88 \%$ of cells) and induced apoptosis in $\sim 70 \%$ of cells proving its efficacy over flavanone. Purified flavonoids exhibited cytotoxicity by disrupting mitochondrial membrane, caspase 3 activation and apoptosis. Purified flavonoids appear as promising natural products for developing cancer therapeutics.
\end{abstract}

$\begin{array}{ll}\text { Abbreviations } \\ \text { AGME } & \text { Andrographis glandulosa methanolic extract } \\ \text { HeLa } & \text { human cervical carcinoma cells } \\ \text { MIA } & \text { PaCapancreatic carcinoma } \\ \text { MMP } & \text { mitochondrial membrane potential } \\ \text { RDA } & \text { retro Diels-Alder reaction } \\ \text { U-87 } & \text { glioblastoma }\end{array}$

\section{Introduction}

Cancer is a global problem with a large number of people being affected and the estimates indicate an increase of $70 \%$ in cases by the end of next 2 decades [1]. Despite the availability of synthetic or semi-synthetic drugs, continued efforts are required to identify naturally occurring safe anticancer compounds that are free from side effects. Plants contributed more than $50 \%$ of anticancer mol- ecules that are being used in the treatment $[2,3]$. The genus Andrographis belonging to the family Acanthaceae includes various species of medicinal importance and most of them are endemic to India. Andrographis paniculata (Burm.f.) Nees is well known and extensively studied at the molecular level $[4,5]$ for its various clinical applications and is being used widely in the preparation of Ayurveda, Siddha, and Unani medicines. The drug lead molecules such as andrographolide and neoandrographolide isolated from this plant exhibited potent anticancer properties [6-8]. Other species like Andrographis lineata Nees, Andrographis nallamalayana J.L.Ellis, Andrographis serpyllifolia (Vahl) Wight, etc. were reported to show antihyperlipidaemic [9], antipsoriatic [10], and anti-inflammatory [11] activities. However, Andrographis glandulosa Nees found in and around forests of the Cuddapah and Nellore districts of Andhra Pradesh, India, [12] is one of the species that remains unraveled for medicinal importance and chemical constituents. 


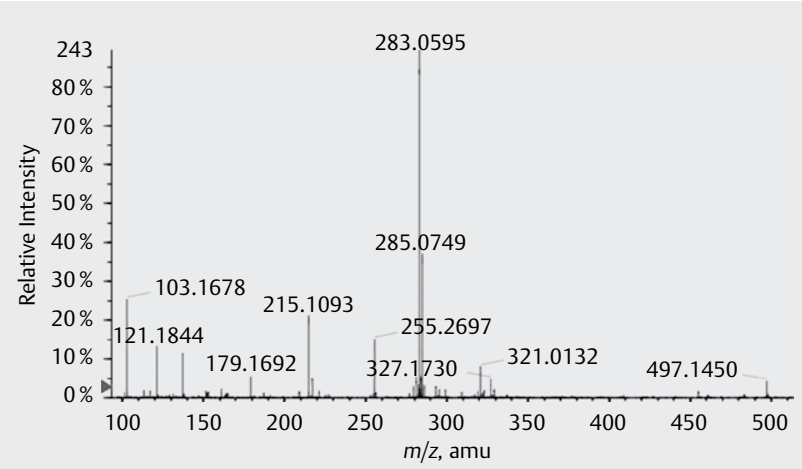

- Fig. 1 Negative ion ESI-MS spectrum of methanolic extract of A. glandulosa.

The focus on the discovery of plant-derived substances followed by biological screening, identification of therapeutic activity, mode of action, and relevant molecular targets led to the identification of potent anticancer molecules such as Vinca alkaloids, curcumin, taxol, etc. Usage of taxol for cancer treatment resulted in drug-resistance over a time period besides preventing mitotic spindle formation in healthy cells causing severe side effects $[13,14]$.

To overcome or minimize the negative effects of the treatment on normal cells, studies to identify novel plant based substances are essential. To date, few species from the genus Andrographis have been assigned with DNA barcodes [15] and exploited for their chemical constituents with various pharmacological activities. The present study, the first of its kind, focused on the profiling of secondary metabolites and determining the structure of major bioactive compounds in addition to evaluating their potential anticancer activity.

\section{Results and Discussion}

The negative ion ESI-MS spectra of AGME, obtained from both instruments, consistently showed 2 major peaks appearing at $\mathrm{m} / \mathrm{z}$ 285.0749 (elemental composition of $\mathrm{C}_{16} \mathrm{H}_{14} \mathrm{O}_{5}$ ) and 283.0595 (elemental composition of $\mathrm{C}_{16} \mathrm{H}_{12} \mathrm{O}_{5}$; > Fig. 1). The accurate mass values of these 2 major peaks, when subjected to metabolite search in online databases, such as Metlin (http://metlin.scripps.edu/index. php), The Human Metabolome Database (http://www.hmdb.ca./ spectra/ms/search), and Metacyc (http://metacyc.org/cpd-search. shtml), revealed that these ions belong to deprotonated molecules, $[\mathrm{M}-\mathrm{H}]^{-}$of flavonoids. Similarly, plausible structures derived for all minor peaks are presented in $>$ Table 1 . Accurate $\mathrm{m} / \mathrm{z}$ values obtained in LC-MS analysis and classification of these metabolites using online database search revealed that AGME is rich in flavonoids consisting of both free aglycones and/or glycosidic conjugates.

LC-total ion current chromatograms (TICC) from triplicate runs consistently showed 2 major peaks at 18.87 and 25.07 min ( $\triangleright$ Fig. 2). The negative ion ESI spectrum of the peak eluted at 18.87 min showed an ion of $\mathrm{m} / \mathrm{z} 285$, and the peak eluted at $25.07 \mathrm{~min}$ showed an ion of $\mathrm{m} / \mathrm{z} 283$ which conformed to respective $\mathrm{m} / \mathrm{z}$ values obtained from direct ESI-MS analyses. The 2 components were successfully isolated by preparative HPLC, and the compounds eluted at 18.87 and 25.07 min were labeled as compound $\mathbf{1}$ and compound $\mathbf{2}$, respectively. The LC-MS analysis of the isolated compounds showed single peaks (data not shown). Purified compounds $\mathbf{1}$ and $\mathbf{2}$ with >95\% purity were analyzed by NMR and MS/MS techniques for elucidating their structures.

The ${ }^{13} \mathrm{C}$ NMR spectrum of compound 1 displayed 16 carbon signals. The ${ }^{1} \mathrm{H}$ NMR signals at $\delta 5.73(1 \mathrm{H}, \mathrm{dd}, \mathrm{J}=3.0,12.9 \mathrm{~Hz}), \delta 3.02$ $(\mathrm{dd}, \mathrm{J}=12.09,17.20 \mathrm{~Hz}$ ) and $\delta 2.85(\mathrm{dd}, \mathrm{J}=3.0,17.20 \mathrm{~Hz}$ ) assigned to $\mathrm{H}_{2}, \mathrm{H}_{3}$-axial, and $\mathrm{H}_{3}$-equitorial, respectively, correspond to the flavanone basic skeleton. Coupling constant values between $\mathrm{H}_{2}$, $\mathrm{H}_{3-\text { axial }}$, and $\mathrm{H}_{3}$-equitorial revealed a stereochemistry at $\mathrm{C}-2$ assigning $\mathrm{R}$ configuration. ${ }^{13} \mathrm{C}$ NMR spectra recorded chemical shift values at $\delta 76.01$ and 42.62 for $C_{2}$ and $C_{3}$, respectively. 2 meta-coupled aromatic doublets $(\mathrm{d}, \mathrm{J}=2.3 \mathrm{~Hz})$ at $\delta 6.06$ and $\delta 6.11$ for $\mathrm{H}_{6}\left(\delta_{C} 94.89\right)$ and $\mathrm{H}_{8}\left(\delta_{\mathrm{C}}\right.$ 95.74) showed the meta-substitution pattern on ring ' $A$ '. A sharp singlet peak in the up field region at $\delta 3.82(3 \mathrm{H}, S), \delta_{C}$ 56.22 represents the presence of one methoxy group on ring ' $A$ ' at C-7 position. A set of 4 signals at $\delta 7.47(\mathrm{dd}, 1 \mathrm{H}, \mathrm{J}=7.5,1.7 \mathrm{~Hz})$, $\delta 7.17$ (ddd, $1 \mathrm{H}, \mathrm{J}=7.5,8.2,1.7 \mathrm{~Hz}), \delta 6.89$ (ddd, $1 \mathrm{H}, \mathrm{J}=7.5,7.5$, $1.2)$ and $\delta 6.82(1 \mathrm{H}, \mathrm{dd}, \mathrm{J}=8.2,1.2 \mathrm{~Hz})$ correspond to 4 adjacent aromatic protons on ring ' $\mathrm{C}$ ' and were assigned as $\mathrm{H}_{6}{ }^{\prime}, \mathrm{H}_{4}$ ', $\mathrm{H}_{5}$ ', and $\mathrm{H}_{3}$ ', respectively. This data revealed a $\mathrm{C}-2$ ' substituted ring ' $\mathrm{C}$ ' and their corresponding ${ }^{13} \mathrm{C}$ NMR analyses disclosed the chemical shift values at $\delta 116.14,127.60,130.33$, and 120.62 ( $\triangleright$ Table 2 ). The UV absorption maximum at $281 \mathrm{~nm}$ revealed a flavanone basic skeleton. The above data assign the structure of compound 1 as 2',5-dihydroxy-7-methoxyflavanone ( $\triangleright$ Fig. 3).

The ${ }^{13} \mathrm{C}$ NMR spectrum of compound 2 showed 16 carbon signals. ${ }^{1} \mathrm{H}$ NMR spectrum showed one sharp 'singlet' at $\delta 7.24$ (specific to flavones) without any further splitting ascribing as $\mathrm{H}_{3}$ proton on ring $\mathbf{B}$, and its corresponding $\delta_{C}$ at $111.10 \mathrm{ppm} .2$ meta-coupled aromatic doublets $(\mathrm{d}, \mathrm{J}=2.3 \mathrm{~Hz})$ at $\delta 6.67$ and $\delta 6.36$ for $\mathrm{H}_{6}\left(\delta_{\mathrm{C}}\right.$ 94.4) and $H_{8}\left(\delta_{C} 99.76\right)$ showed the presence of meta-substitution pattern on ring ' $A$ '. The spectrum also showed one sharp singlet peak in the up field region at $\delta 3.87(3 \mathrm{H}, S), \delta_{C} 57.89$ corresponding to one methoxy group on ring ' $A$ '. A set of 4 signals at $\delta 7.94$ (dd, $1 \mathrm{H}, \mathrm{J}=8.0,1.6 \mathrm{~Hz}$ ), $\delta 7.34$ (ddd, $1 \mathrm{H}, \mathrm{J}=8.3,7.3,1.6 \mathrm{~Hz}$ ), $\delta 7.01$ $(\mathrm{ddd}, 1 \mathrm{H}, \mathrm{J}=8.0,7.3,1.0)$, and $\delta 6.98(1 \mathrm{H}, \mathrm{dd}, \mathrm{J}=8.3,1.0 \mathrm{~Hz})$ revealed the presence of 4 adjacent aromatic protons on ring ' $C$ ' assigned to $\mathrm{H}_{6}{ }^{\prime}, \mathrm{H}_{4}{ }^{\prime}, \mathrm{H}_{5}$ ' and $\mathrm{H}_{3}{ }^{\prime}$, respectively, with corresponding ${ }^{13} \mathrm{C}$ chemical shifts $118.77,130.38,134.90$, and 121.29 ( $\triangleright$ Table 2). The UV absorption maxima at 210,245 , and $260 \mathrm{~nm}$ correspond to a typical flavone skeleton. The above data assign the structure of compound $\mathbf{2}$ as 2',5-dihydroxy-7-methoxyflavone ( $\mathbf{F i g . ~ 3 ) . ~}$

Negative ion ESI mass spectrum of compound 1 showed a [M$\mathrm{H}]$ - ion at $\mathrm{m} / \mathrm{z} 285.07575$ corresponding to the elemental composition $\mathrm{C}_{16} \mathrm{H}_{14} \mathrm{O}_{5}$. The MS/MS spectrum of ion $\mathrm{m} / \mathrm{z} 285$ recorded the product ions expected to be formed due to the fragmentation of flavanone aglycones ( $\triangleright$ Fig. 4). One prominent product ion appeared at $\mathrm{m} / \mathrm{z} 165$ corresponding to the loss of $\mathrm{C}_{8} \mathrm{H}_{8} \mathrm{O}$ from $[\mathrm{M}-\mathrm{H}]^{-}$ ion, representing a RDA reaction. The other RDA product ion leaving charge on substituted styrene part with $\mathrm{m} / \mathrm{z} 119$ appeared with low abundance. These RDA product ions conform to the presence of hydroxy and methoxy substituents on ring 'A' and a hydroxy substituent on ring ' $C$ ' ( $\triangleright$ Fig. 4). Other product ions in the MS/MS spectrum of compound 1 which appeared at $\mathrm{m} / \mathrm{z} 270$ and 242 correspond to the loss of $\mathrm{CH}_{3}$ and $\left(\mathrm{CH}_{3}+\mathrm{CO}\right)$ radical, respectively, from $[\mathrm{M}-\mathrm{H}]^{-}$ion. This fragmentation pattern supports the structure of the compound $\mathbf{1}$ as 2',5-dihydroxy-7-methoxyflavanone. 
- Table 1 Plausible structures of 8 minor peaks identified in LC-MS analysis.

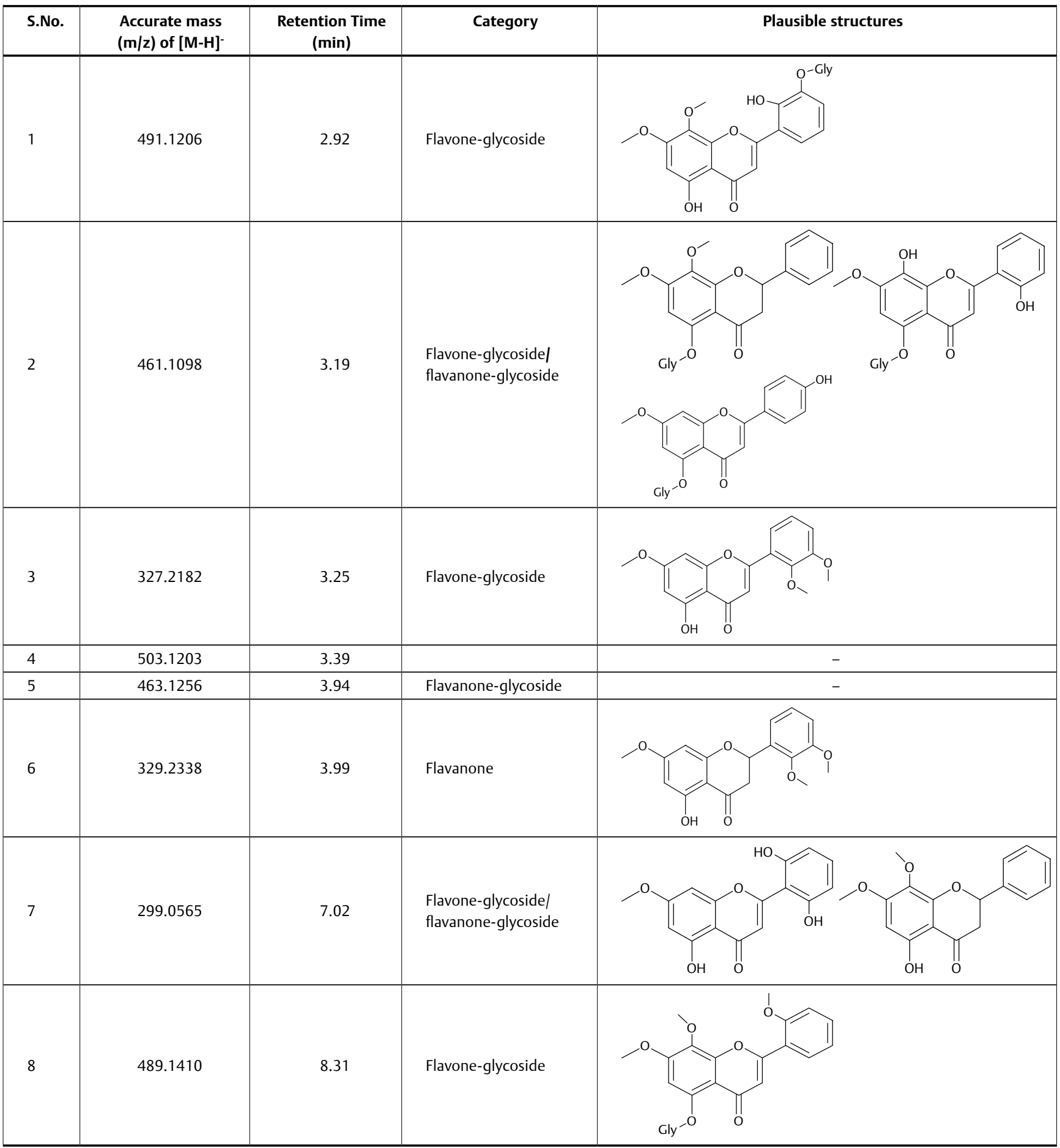

Negative ion ESI mass spectrum of compound 2 showed the [M$\mathrm{H}]$ - ion at $\mathrm{m} / \mathrm{z} 283.0609$ corresponding to the elemental composition $\mathrm{C}_{16} \mathrm{H}_{12} \mathrm{O}_{5}$. Comparison of MS data of compound 2 with that of compound 1 revealed an extra unsaturation (double bond) in compound 2. MS/MS spectrum of ion $\mathrm{m} / \mathrm{z} 283$ showed the product ions characteristic of flavone aglycone ( $\mathbf{F i g} . \mathbf{5})$. The major product ion at $\mathrm{m} / \mathrm{z} 165$ is the result of RDA reaction ( $\mathbf{F i g . ~} \mathbf{5}$ ) and showed the presence of hydroxy and methoxy substituents in the ring ' $A$ ' (flavone structure). Other RDA product ion retaining charge on the substituted ethynyl benzene which appeared at m/z 117 correspond to the molecular formula $\mathrm{C}_{8} \mathrm{H}_{6} \mathrm{O}$. This ion provides the information about the presence of a hydroxyl group in ring ' $C$ ' with ethynyl phenol type of structure. Other products that appeared in the spectrum at $\mathrm{m} / \mathrm{z} 268$ (loss of $\mathrm{CH}_{3}$. from m/z 283), m/z 240 [loss of $\left(\mathrm{CH}_{3}+\mathrm{CO}\right) \cdot$ from $\left.\mathrm{m} / \mathrm{z} 283\right]$ and $\mathrm{m} / \mathrm{z} 121$ correspond to the loss of $\mathrm{CO}_{2}$ from $\mathrm{m} / \mathrm{z} 165$. This fragmentation pattern supports the structure of the compound 2 as 2',5-dihydroxy-7-methoxyflavone. 
The antiproliferative activity of purified flavanone and flavone on 3 different cell lines is presented in $>$ Fig. 6. SRB assay results revealed varying $I C_{50}$ values for purified compound $\mathbf{1}(\mathrm{m} / \mathrm{z} 285)$ on

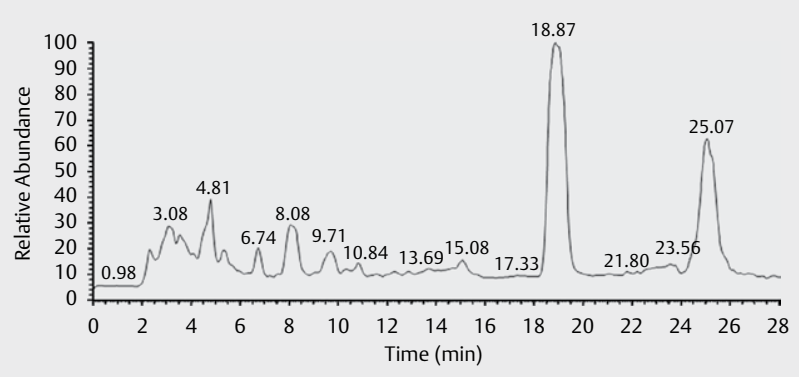

- Fig. 2 Total ion chromatogram of methanolic extract of A. glandulosa. LC-MS of A. glanduosa showing 2 major peaks at 18.87 and $25.07 \mathrm{~min}$ of retention time with an $\mathrm{m} / \mathrm{z}$ of 285 and 283 , respectively.

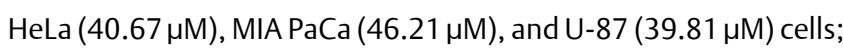
whereas, compound $\mathbf{2}(\mathrm{m} / \mathrm{z} 283)$ exhibited higher antiproliferative activity with an $\mathrm{IC}_{50}$ of $20.84 \mu \mathrm{M}$ on HeLa, $24.36 \mu \mathrm{M}$ in MIA PaCa, and $25.16 \mu \mathrm{M}$ in $\mathrm{U}-87$ cells. The positive control quercetin exhibited an $\mathrm{IC}_{50}$ of $25.16 \mu \mathrm{M}$ on HeLa, $26.82 \mu \mathrm{M}$ in MIA PaCa, and $21.78 \mu \mathrm{M}$ in U-87 cells. Both the aglycones viz., 2',5-dihydroxy7-methoxyflavanone (m/z 285) and 2',5-dihydroxy-7-methoxyflavone ( $\mathrm{m} / \mathrm{z} 283$ ), purified from A. glandulosa, exhibited antiproliferative activity in a dose-dependent manner.

Flavonoids are polyphenolic compounds which are known to exhibit a wide range of pharmacological activities and are considered as prospective compounds for cancer therapy [16]. A considerable number of in vitro and in vivo studies have been carried out using natural flavonoids to establish the correlation between the flavonoid structure and their activity. In an earlier study, the flavonoids apigenin and chrysin having flavone basic skeletons exhibited potent anticancer activity. Apigenin was found to be effective in multiple ways, by inhibiting protein kinase $C$, phosphatidylinositol

- Table $2{ }^{1}$ HNMR and ${ }^{13}$ CNMR derived chemical shift values of the 2 purified compounds.

\begin{tabular}{|c|c|c|c|c|c|c|}
\hline \multirow[b]{2}{*}{ Position } & \multicolumn{3}{|c|}{ Compound 1 (RT $19 \mathrm{~min}$ and $\mathrm{m} / \mathrm{z} 285$ ) } & \multicolumn{3}{|c|}{ Compound 2 (RT $25 \mathrm{~min}$ and $\mathrm{m} / \mathrm{z} 283$ ) } \\
\hline & ${ }^{1} \mathrm{HNMR}\left(\mathrm{CD}_{3} \mathrm{OD}\right) \delta_{\mathrm{H}} \mathrm{ppm}$ & $\mathrm{J}(\mathrm{Hz})$ & ${ }^{13} \mathrm{CNMR} \delta_{\mathrm{C}} \mathrm{Ppm}$ & ${ }^{1} \mathrm{HNMR}\left(\mathrm{CD}_{3} \mathrm{OD}\right) \delta_{\mathrm{H}} \mathrm{Ppm}$ & $\mathrm{J}(\mathrm{Hz})$ & ${ }^{13} \mathrm{CNMR} \delta_{\mathrm{C}} \mathrm{Ppm}$ \\
\hline 2 & 5.73 & $3.00,12.9$ & 76.01 & & & 159.3 \\
\hline 3 & ax 3.02 & $12.9,17.2$ & 42.62 & 7.24 & & 111.1 \\
\hline & eq 2.85 & $3.00,17.2$ & & & & \\
\hline 4 & & & 188.8 & & & 178.3 \\
\hline 5 & & & 158.9 & & & 149.5 \\
\hline 6 & 6.11 & 2.3 & 94.89 & 6.67 & 2.2 & 94.4 \\
\hline 7 & & & 164.3 & & & 151.6 \\
\hline 8 & 6.06 & 2.3 & 95.74 & 6.36 & 2.2 & 99.76 \\
\hline 9 & & & 164.5 & & & 146.2 \\
\hline 10 & & & 106.3 & & & 109.5 \\
\hline 1' & & & 124.6 & & & 117.1 \\
\hline $2^{\prime}$ & & & 153.6 & & & 156.7 \\
\hline $3^{\prime}$ & 6.82 & $8.2,1.2$ & 116.14 & 6.98 & $8.3,1.00$ & 118.77 \\
\hline $4^{\prime}$ & 7.17 & $7.5,8.2,1.7$ & 130.33 & 7.34 & $8.3,7.3,1.6$ & 134.9 \\
\hline $5^{\prime}$ & 6.89 & $7.5,7.5,1.2$ & 120.62 & 7.01 & $8,7.3,1.00$ & 121.29 \\
\hline $6^{\prime}$ & 7.47 & $7.5,1.7$ & 127.6 & 7.94 & $8,1.6$ & 130.38 \\
\hline $\mathrm{OCH}_{3}-7$ & 3.82 & & 56.22 & 3.87 & & 57.89 \\
\hline $\mathrm{OH}-5$ & 10.74 & & & 10.71 & & \\
\hline $\mathrm{OH}-2^{\prime}$ & 9.31 & & & 9.29 & & \\
\hline
\end{tabular}
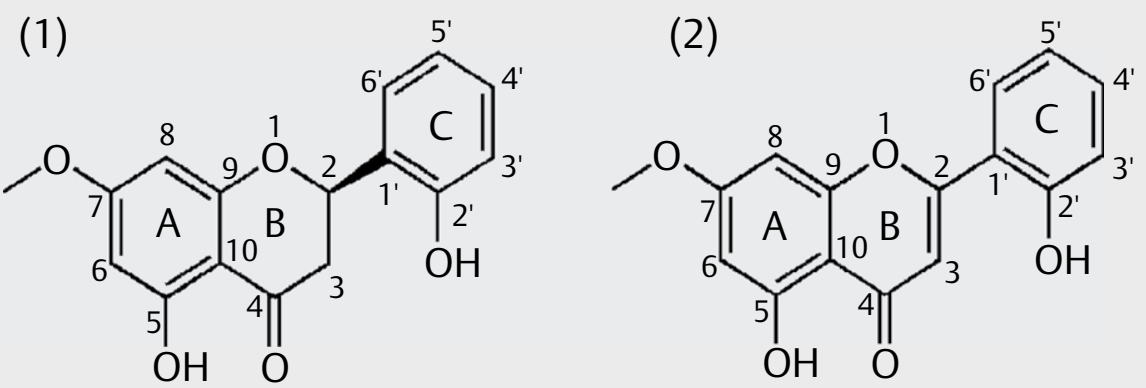

- Fig. 3 Molecular structure of the 2 purified compounds obtained at an RT 18.87 and 25.07 min. Compound 1: 2', 5-dihydroxy-7-methoxyflavanone; Compound 2: 2', 5-dihydroxy-7-methoxyflavone. 

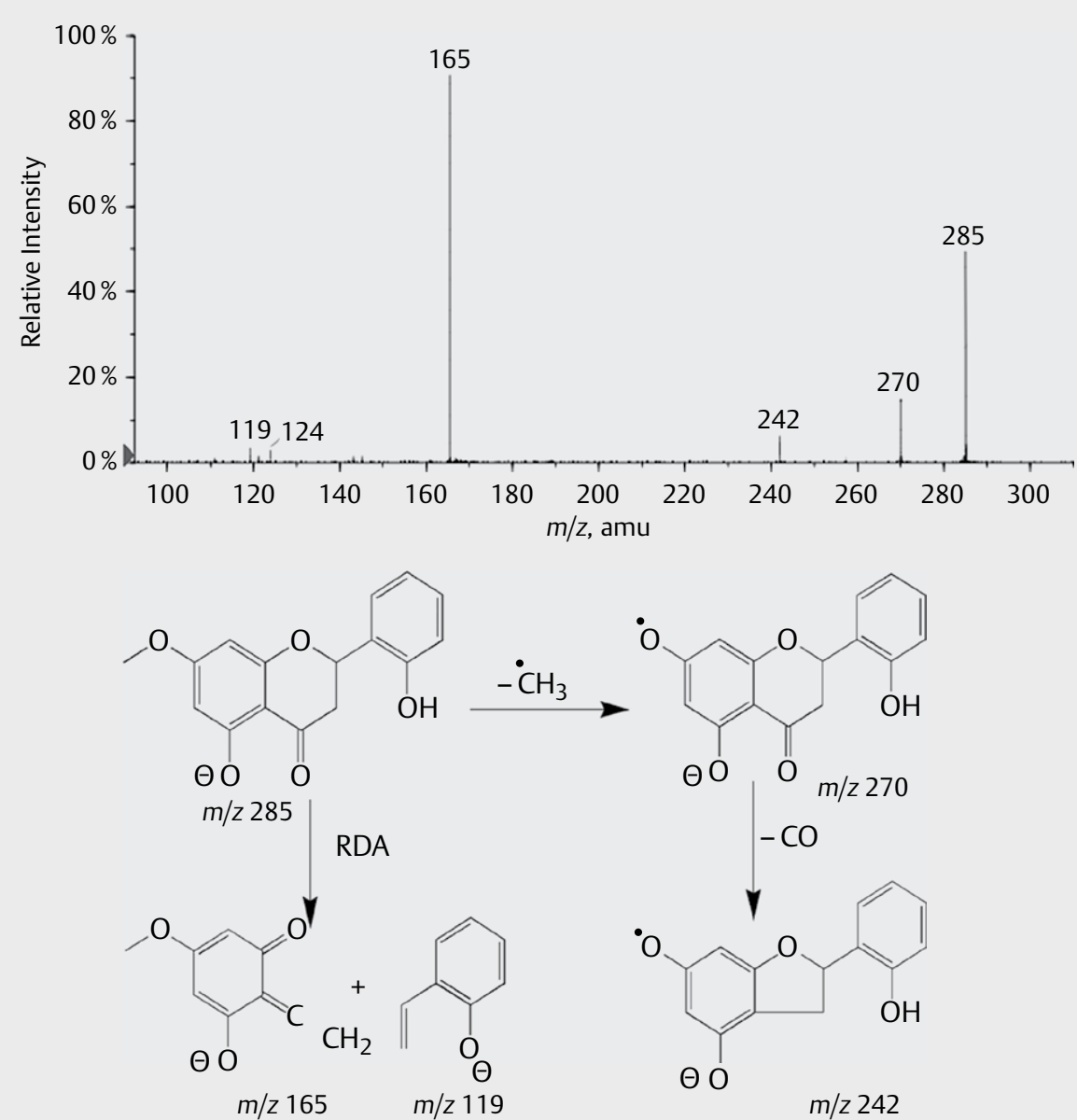

- Fig. 4 ESI-MS/MS spectrum of the m/z $285\left[^{M-H}\right]^{-}$ion. Scheme shows its CID mass fragmentation pattern.

3-kinase (PI 3-kinase a) and also by blocking of the cell cycle at G2/M phase; whereas, chrysin was found effective in inhibiting topoisomerase II activity [17]. Similarly, another flavone, luteolin, was found to inhibit growth of HAK-1B hepatoma cells in xenografted mice by targeting signal transducer and activator of transcription 3 gene (STAT 3) by either ubiquitin dependent degradation in $\mathrm{Tyr}^{705}$-phosphorylated STAT3 and/or by down-regulation in Ser ${ }^{727}$. phosphorylated STAT3 through inactivation of CDK5, triggering apoptosis via up-regulation of Fas/CD95 [18]. Flavonoids are known to inhibit the action of CYP450s involved in the metabolic activation of procarcinogens and are also known to activate the enzymes like UDP-glucuronyl transferase, quinone reductase, and glutathione-S-transferase that are involved in detoxification and elimination of carcinogens [19]. A wide diversity in the structural patterns of flavonoids with varied targets provides a greater opportunity for identifying effective pharmacophores with potential anticancer properties. Flavonoids isolated from medicinal plants such as Andrographis lineata Nees [20], Cassia tora L. (Leguminosae) [21], and Glycyrrhiza inflata Batalin (Leguminosae) [22] exhibited potent anticancer activity. Flavonoids were found effective in inducing apoptosis, [23] arresting cell cycle by disrupting the mitotic spindle formation [24], and inhibiting angiogenensis [25, 26] in various cancers. In another study, a herbal formulation (Shemamruthaa) rich in flavonoid content was found effective in inhibiting the proliferation of breast cancer cells [27]. Flavonoids such as quercetin, luteolin and 3-O-methylquercetin, isolated from Achyrocline satureioides (Lam.) DC. (Compositae), were found promising for cancer therapy [28].

Effects of purified compounds on MMP and apoptosis are presented in $>$ Table 3. HeLa cells treated with 57 or $117 \mu \mathrm{M}$ of the purified compound 1 (2', 5-dihydroxy-7-methoxyflavanone) ( $>$ Fig. 7) showed a loss of MMP in $26.5 \%$ ( $\triangleright$ Fig. $7 c$ ) or $54.8 \%$ of cells ( $\triangleright$ Fig. $7 d$ ) and the cells treated with 40 or $80 \mu \mathrm{M}$ of the purified compound 2 (2', 5-dihydroxy-7-methoxyflavone) exhibited a loss of MMP in $34.1 \%$ ( $\triangleright$ Fig. 7e) and $87.7 \%$ of cells ( $\triangleright$ Fig. 7f). The cells treated with $50 \mu \mathrm{M}$ of the positive control quercetin showed a loss of MMP in $24.3 \%$ of cells ( $\mathbf{F i g}$. 7 b). Similarly, the cells treated with 57 or $117 \mu \mathrm{M}$ of the purified compound $\mathbf{1}(\triangleright \mathbf{F i g} . \mathbf{8}$ ) resulted in $14 \%$ ( $>$ Fig. 8 c) or $50.6 \%$ ( $\triangleright$ Fig. 8 d) of apoptotic cells and the cells treated with 40 or $80 \mu \mathrm{M}$ of the purified compound 2 resulted in $30.4 \%$ ( $\triangleright$ Fig. 8 e) or $69.6 \%$ ( $\vee$ Fig. 8 f) of apoptotic cells. The cells treated with the positive control quercetin showed apoptosis in $32.5 \%$ of cells ( $\triangleright$ Fig. 8b). Apoptosis is a genetically programmed mechanism that can be induced through several molecular pathways. Mitochondria were found to play a key role in the process of apoptosis [29]. It was reported that prior to the common signs of nuclear apoptosis such as chromatin condensation and endonuclease-mediated DNA fragmentation, the cells exhibit reduction in the MMP 

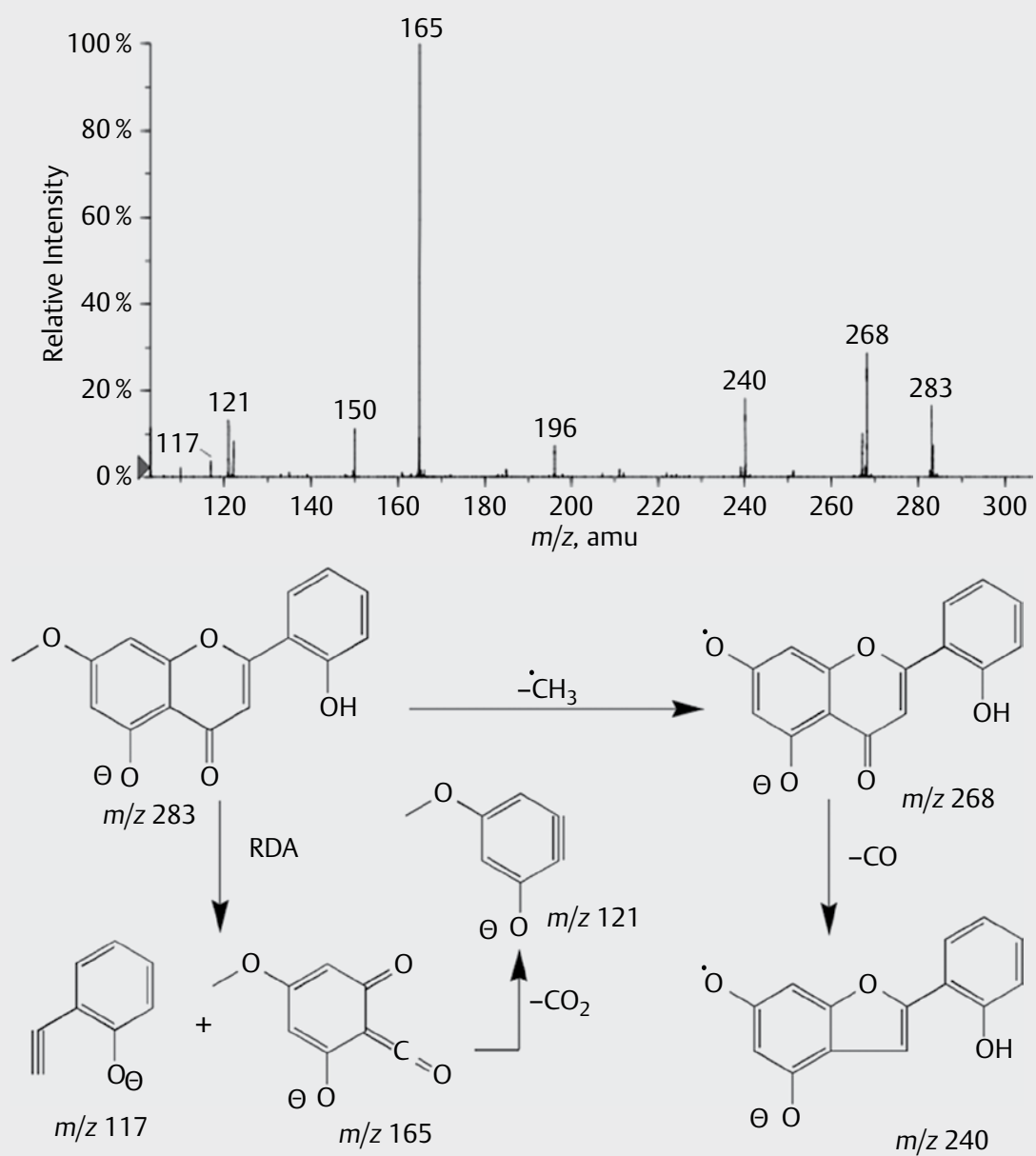

Fig. 5 ESI-MS/MS spectrum of the m/z $283[\mathrm{M}-\mathrm{H}]^{-}$ion. Scheme shows its CID mass fragmentation pattern.
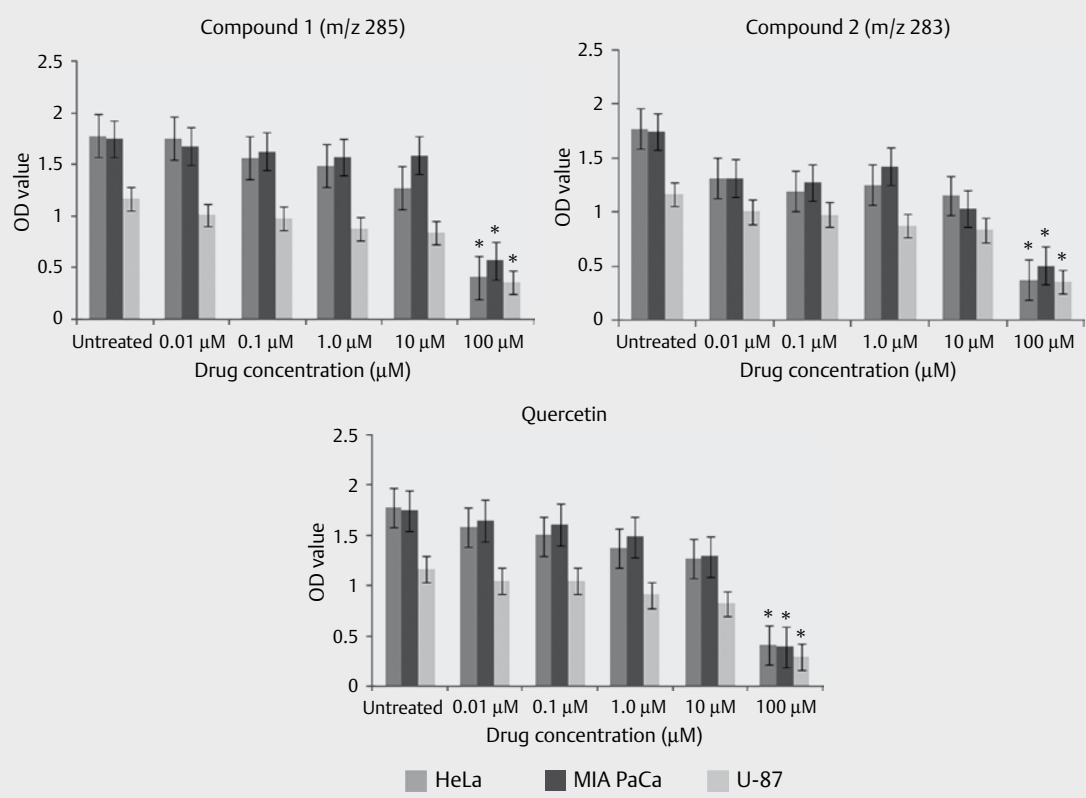

- Fig. 6 Antiproliferative activity of purified flavonoids on 3 cancer cell lines. Treatment with different concentrations of purified flavonoids and standard compound quercetin. ${ }^{*} \mathrm{p}$ value $<0.01$ was considered to be statistically significant (data is average of 3 replicates). 
- Table 3 Treatment of HeLa cells with purified flavonoids induced mitochondrial membrane depolarization and apoptosis.

\begin{tabular}{|l|c|c|c|c|c|c|}
\hline & \multicolumn{2}{|c|}{ Compound 1 (m/z 285) } & \multicolumn{2}{c|}{ Compound 2 (m/z 283) } & Untreated & Quercetin \\
\hline Concentration $(\mu \mathrm{M})$ & 57 & 117 & 40 & 80 & - & 50 \\
\hline MMP & $1342 \pm 17^{*}$ & $2694 \pm 46^{*}$ & $1712.5 \pm 7.5^{*}$ & $4388 \pm 3^{*}$ & $320 \pm 1.5$ & $1215 \pm 3.5^{*}$ \\
\hline APOPTOSIS & $690 \pm 10^{*}$ & $2528 \pm 2^{*}$ & $1516 \pm 4^{*}$ & $3467 \pm 13^{*}$ & $226 \pm 3$ & $1625 \pm 7.07^{*}$ \\
\hline
\end{tabular}

Mean number of cells (mean \pm SEM) showing mitochondrial depolarization/apoptosis (data is average of 3 replicates); ${ }^{*} \mathrm{p}$ value $<0.01$ was considered to be statistically significant
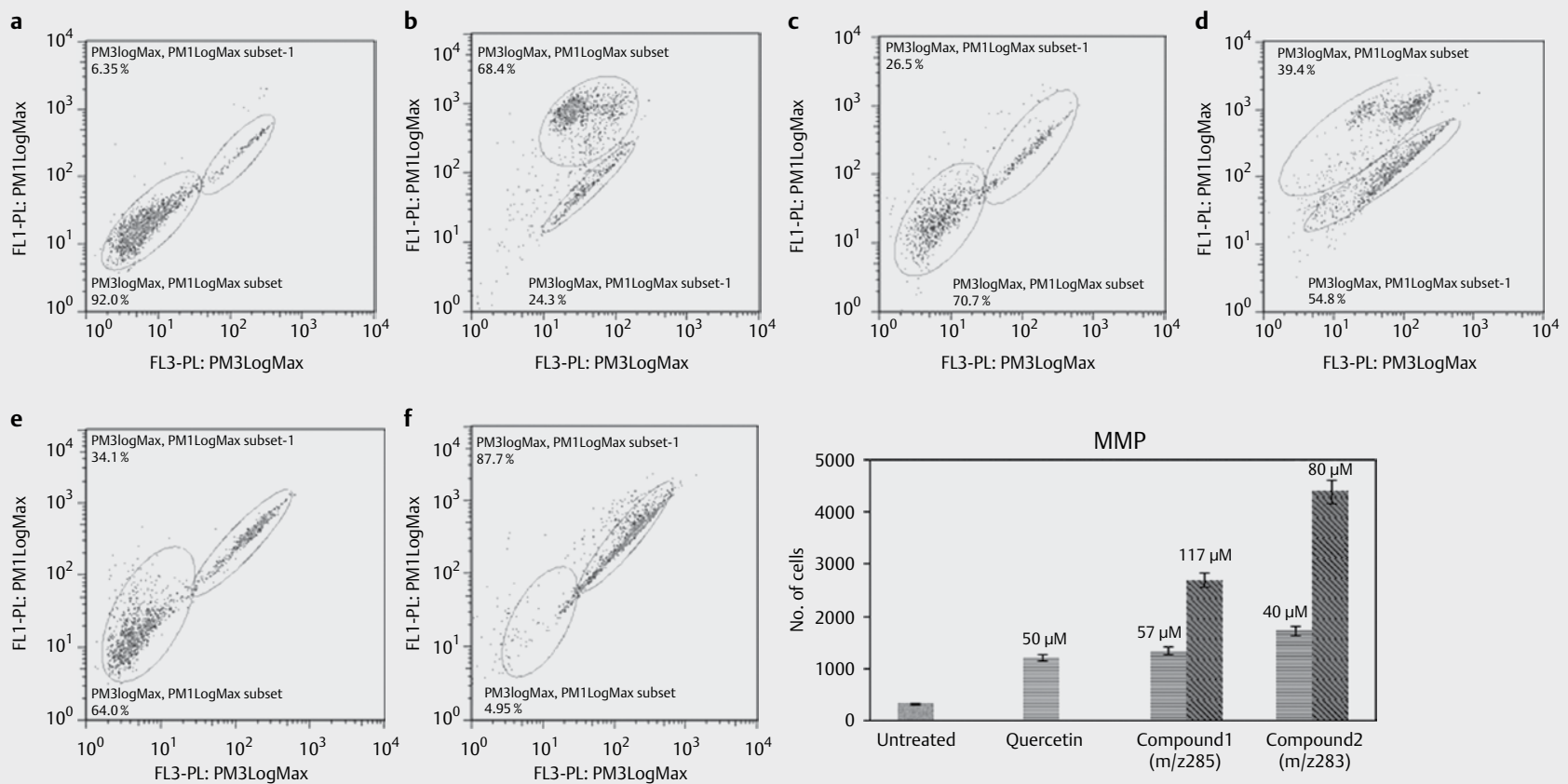

- Fig. 7 Effect of the purified flavonoids on MMP in HeLa cells. Depolarized cells dispersed towards PM3 log max a. Untreated control showing $6.35 \%$ of depolarized cells b. Cells treated with $50 \mu \mathrm{M}$ of positive control Quercetin showing $24.3 \%$ depolarized cells $\mathbf{c}$, $\mathbf{d}$. Cells treated with $57 \mu \mathrm{M}$ or $117 \mu \mathrm{M}$ of 2', 5-dihydroxy-7-methoxyflavanone showing $26.5 \%$ or $54.8 \%$ depolarized cells e, f. Cells treated with $40 \mu \mathrm{M}$ or $80 \mu \mathrm{M}$ of 2', 5-dihydroxy7-methoxyflavone showing $34.1 \%$ or $87.7 \%$ of depolarized cells.

leading to the opening of mitochondrial permeability transition pores [30]. It was also shown that mitochondrial depolarization occurs by the release of cytochrome $c$ from the mitochondria into the cytosol which forms an essential part of the apoptosome [31, 32]. Of the 2 compounds studied, flavone revealed a higher anticancer activity compared to that of flavanone owing to its potential resonance, efficient electron delocalization and its stable flat structure.

To understand the mechanism involved in apoptosis, activation of caspase 3 was evaluated by Western blotting. As compared to untreated HeLa cells, treatment with $50 \mu \mathrm{M}$ of purified flavonoids for $24 \mathrm{~h}$ showed a drastic increase in the cleaved caspase 3 ( $\mathbf{F i g . ~ 9 ) . ~}$ Purified flavonoids caused a loss of mitochondrial membrane potential and this change in membrane permeability results in the release of specific proteins such as cytochrome $\mathrm{c}$ responsible for the activation of caspase 9 which in turn cleaves zymogen procaspase 3 into $p 17$ and $p 12$. The oligomerizations of these cleaved subunits are known to result in the formation of active executioner caspase 3. Tetrameric active caspase 3 is known to cleave proteins such as caspase 2, caspase 6, nuclear lamin, nuclear-DNA-dependent protein kinase, and DNA fragmentation factor 45 responsible for ap- optosis [33, 34]. In conclusion, this study, the first of its kind, unravels the medicinal importance of $A$. glandulosa as it is a rich source of bioactive flavonoids and the 2 purified flavonoids seem promising for the development of therapeutic formulations for treating cancer.

\section{Materials and Methods}

\section{Ethics statement}

Plants used in the present investigation are neither endangered nor protected species and specimens were collected from open areas not requiring any permits.

\section{Preparation of plant extracts}

Plants of A. glandulosa (voucher id: CNS04AG2013) were collected from the Cuddapah district. Identification of the species was done based on the taxonomic literature and authentication given by Deccan Circle, Botanical Survey of India. The plant materials were shade dried and cut into small pieces. The dried material $(10 \mathrm{~g})$ has been 

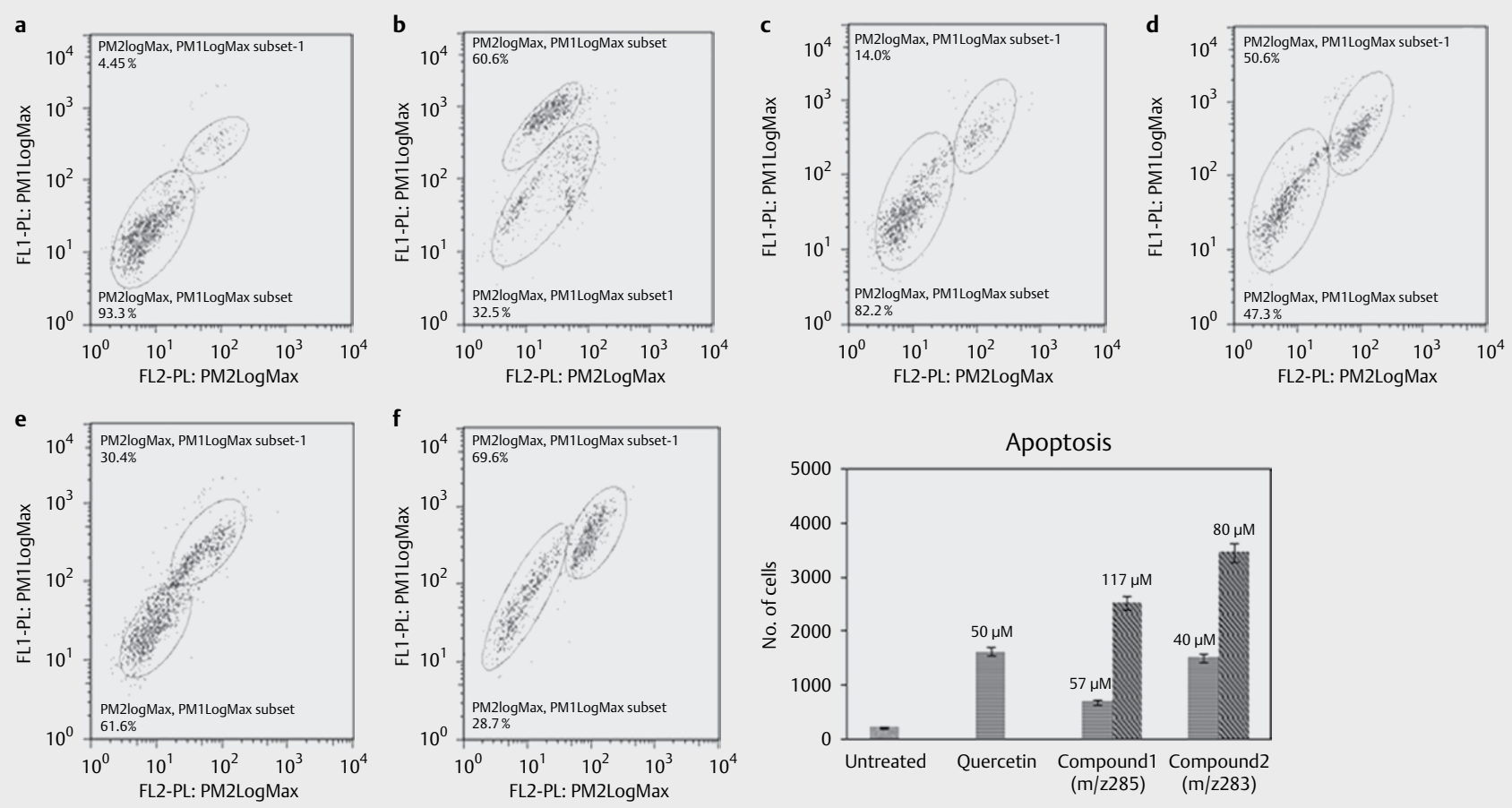

- Fig. 8 Effect of the purified flavonoids on apoptosis in HeLa cells. Apoptotic cells dispersed towards PM2 log max a. Untreated control showing $4.45 \%$ of the apoptotic cells $\mathbf{b}$. Cells treated with $50 \mu \mathrm{M}$ of positive control Quercetin showing $32.5 \%$ of apoptotic cells $\mathbf{c}$, d. Cells treated with $57 \mu \mathrm{M}$ or $117 \mu \mathrm{M}$ of 2', 5-dihydroxy-7-methoxyflavanone showing $14 \%$ or $50.6 \%$ of apoptotic cells e, f. Cells treated with $40 \mu \mathrm{M}$ or $80 \mu \mathrm{M}$ of 2', 5-dihydroxy7 -methoxyflavone showing $30.4 \%$ or $69.6 \%$ of apoptotic cells.
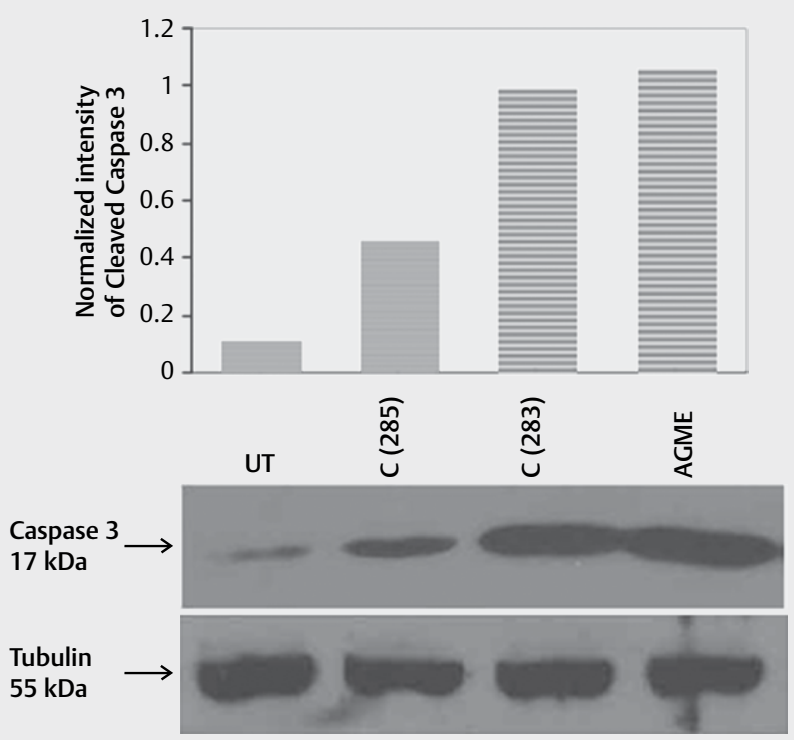

- Fig. 9 Immunoblot of cleaved caspase 3 in lysates of HeLa cells treated with purified flavonoids. UT: Untreated control; $C(285)$ : Compound $1(50 \mu \mathrm{M})$; C(283): Compound $2(50 \mu \mathrm{M})$; AGME: methanolic extract of A. glandulosa $(100 \mu \mathrm{g})$.

ground into fine powder and subjected to soxhlet extraction in $300 \mathrm{~mL}$ of $100 \%$ methanol (Merck) at $65^{\circ} \mathrm{C}$. The resulting extract (AGME) was filtered using whatman filter paper and vacuum dried to remove trace amounts of methanol, if any.

\section{Sample preparation for metabolite analysis}

Methanol ( $1 \mathrm{~mL}$ ) was added to the dried crude extract $(2 \mathrm{mg})$, vortexed for $5 \mathrm{~min}$ and the resulting solution was centrifuged for $5 \mathrm{~min}$ at $10000 \mathrm{rpm}$. The supernatant was transferred into another fresh vial and concentrated to $500 \mu \mathrm{L}$ using Scanvac. The resulting solution was either immediately subjected for mass spectrometry analysis or stored in the refrigerator $\left(4^{\circ} \mathrm{C}\right)$ until further analyses.

\section{Direct ESI-MS and ESI-MS/MS analyses}

Direct ESI-MS analyses were performed on a high resolution Q-TOF mass spectrometer (Q-Star XL, Applied Biosystems). Prior to sample analysis, methanol was injected into ESI-MS as solvent blank to rule out the background peaks. The spectral data was processed using Analyst software. Methanol was used as a mobile phase with a flow rate of $30 \mu \mathrm{L} / \mathrm{min}$ and the samples were introduced into the source by the flow injection mode. Typical ESI conditions like $5.00 \mathrm{kV}$ capillary voltage, $60 \mathrm{~V}$ declustering potential, $220 \mathrm{~V}$ focusing potential, $10000 \mathrm{FWHM}$ (Full Width at Half Maximum) as instrument resolution were employed. Analyses were carried out in triplicates under similar experimental conditions.

For ESI-MS/MS analyses the precursor ion of interest was selected using the quadrupole analyzer, collisions were made with nitrogen gas in the collision cell and resulted product ions were analyzed by TOF analyzer. Spectra were recorded using a collision energy of $30 \mathrm{eV}$.

\section{LC-MS and LC-photodiode array analyses}

LC-MS and LC-photodiode array (PDA) analyses were performed on an Exactive Orbitrap mass spectrometer (Thermo Scientific) cou- 
pled with a Thermo Accela 600 UHPLC pump and an Accela autosampler (Thermo Scientific). The chromatographic separation was achieved on a Zorbax Eclipse Plus C18 column $(4.6 \times 150 \mathrm{~mm}$, $3.5 \mu \mathrm{m}$; Agilent). 2-component mobile phase consisting of methanol and water in 65:35 (v/v) composition was employed under isocratic mode with a run time of $28 \mathrm{~min}$. Injection volume and flow rates were $8 \mu \mathrm{L}$ and $0.6 \mathrm{~mL} / \mathrm{min}$, respectively, while the column temperature was maintained at $25^{\circ} \mathrm{C}$. For MS analysis, the LC eluents were allowed to enter into a heated electrospray ionization (HESI) probe with typical operational conditions of $300^{\circ} \mathrm{C}$ probe temperature, $280^{\circ} \mathrm{C}$ capillary temperature, $85 \mathrm{~V}$ capillary voltage, $4.5 \mathrm{kV}$ spray voltage, and $175 \mathrm{~V}$ tube lens voltage. Nitrogen was used as both auxiliary and sheath gas at a flow rate of 45 and $15 \mathrm{~mL} / \mathrm{min}$, respectively. Mass range m/z 100 to 1000 and resolution of 40000 (FWHM) was employed. For LC-PDA analyses, the LC eluents were allowed to enter a Photo Diode Array detector (Accela PDA, $80 \mathrm{~Hz}$ ) operated at the range of ultraviolet-visible wavelength $(200 \mathrm{~nm}$ to $600 \mathrm{~nm}$ ) using Deuterium and Tungsten lamps. Data was acquired using Xcalibur software (Thermo Scientific).

\section{Isolation of major compounds by preparative HPLC}

The purification of both compounds corresponding to the 2 major peaks was carried out on a preparative HPLC (Waters) equipped with E0860F quaternary pump and PDA detector. Column specifications and mobile phase composition were same as mentioned in LC-PDA analysis. Dried methanolic extract of $100 \mathrm{mg}$ was dissolved in $4 \mathrm{~mL}$ of pure methanol. A sample of $10 \mu \mathrm{L}$ was injected and run for $30 \mathrm{~min}$. To get a sufficient amount of each compound the experiment was repeated. At each run the first fraction was collected from retention time (RT) of 18.50 to $19.50 \mathrm{~min}$, while the second fraction was collected from RT of 24.50 to $25.50 \mathrm{~min}$. All the fractions collected for specific RT were pooled up in a round bottom flask. Rotary evaporation was done to get the compounds in a solid form free of solvent. The purity of the isolated compounds was authenticated by LC-MS analyses. The pure compounds were subjected to NMR, MS/MS analyses for structure determination and further evaluated for the anticancer activity.

\section{NMR analyses}

NMR analyses were performed on AV-III 500 and AV-II $600 \mathrm{MHz}$ NMR spectrometers at room temperature using the compounds dissolved in Methanol- $\mathrm{D}_{4}\left(\mathrm{CD}_{3} \mathrm{OD}\right)$ solvent. Residual methyl signal of solvent was used as internal reference. All the chemical shifts were measured in a $1 \mathrm{D}$ NMR $\left({ }^{1} \mathrm{H} \&{ }^{13} \mathrm{C}\right.$ NMR $)$ spectrum and coupling constants were measured with resolution enhanced 1D spectrum. Chemical shift correlations were done using ${ }^{1} \mathrm{H}-{ }^{1} \mathrm{H}$ double quantum filtered correlation (DQFCOSY) and ${ }^{1} \mathrm{H}-{ }^{13} \mathrm{C} \mathrm{HSQC} / \mathrm{HMBC}$ spectra. These $2 \mathrm{D}$ spectra were processed with a Gaussian apodization in both dimensions.

\section{SRB assay of purified flavonoids}

The cell lines, HeLa (doubling time: 19h), MIA PaCa (doubling time: $40 \mathrm{~h}$ ), and U-87 (doubling time: $34 \mathrm{~h}$ ) used in this study were procured from American Type Culture Collection (ATCC). Purified flavonoids and quercetin, as positive control, (Sigma \#Q4951, $\geq 95 \%$ purity) were evaluated for their in vitro anti-proliferative activity. Sulforhodamine B (SRB) cell proliferation assay was used to estimate cell viability after treating the cells with purified compounds for $48 \mathrm{~h}$. All cell lines were grown in DMEM (containing $10 \%$ FBS) in a humidified atmosphere of $5 \% \mathrm{CO}_{2}$ at $37^{\circ} \mathrm{C}$. Cells cultured in $\mathrm{T} 25$ flasks were trypsinized after attaining subconfluent stage and seeded in 96-well plates in $100 \mu \mathrm{L}$ aliquots at plating densities depending on the doubling time of individual cell lines. The microtiter plates were incubated at $37{ }^{\circ} \mathrm{C}, 5 \% \mathrm{CO}_{2}, 95 \%$ air and $100 \%$ relative humidity. After $24 \mathrm{~h}$ of incubation, purified compounds with different concentrations $(0.01,0.1,1,10$, and $100 \mathrm{mM})$ were added and incubated for $48 \mathrm{~h}$. After $48 \mathrm{~h}$ of incubation at $37^{\circ} \mathrm{C}$, cell monolayers were fixed by the addition of $10 \%(\mathrm{wt} / \mathrm{vol}$ ) cold trichloroacetic acid and incubated at $4{ }^{\circ} \mathrm{C}$ for $1 \mathrm{~h}$ and were stained with $0.057 \%$ SRB dissolved in $1 \%$ acetic acid for $30 \mathrm{~min}$ at room temperature. Unbound SRB was washed with $1 \%$ acetic acid. The protein-bound dye was dissolved in $10 \mathrm{mM}$ Tris base solution and OD was measured at $510 \mathrm{~nm}$ using a microplate reader (Enspire, Perkin Elmer).

\section{Analysis of flavonoid-induced mitochondrial membrane depolarization and apoptosis by flow cytometry}

HeLa cells were cultured for $24 \mathrm{~h}$ in 12 well plates $\left(3 \times 10^{4}\right.$ cells $\left./ \mathrm{mL}\right)$ and treated with $57 \mu \mathrm{M} / 117 \mu \mathrm{M}$ of compound 1 or $40 \mu \mathrm{M} / 80 \mu \mathrm{M}$ of compound 2 for $24 \mathrm{~h}$. Quercetin $(50 \mu \mathrm{M})$ was used as positive control. Media were removed from each well and washed with 1 X PBS. Cells were trypsinized with 0.125 \% Trypsin EDTA (Himedia \#TCL042) for one minute and the cell pellet was collected by centrifugation at $300 \times \mathrm{g}$ for $2 \mathrm{~min}$. Cells were resuspended in $6 \mathrm{~mL}$ of complete culture medium and the cell concentration was maintained at $2 \times 10^{4}$ cells $/ \mathrm{mL}$. From this $200 \mu \mathrm{L}$ of cells were aliquoted into $1.5 \mathrm{~mL}$ eppendorf tubes and following the manufacturer's protocol, changes in the mitochondrial membrane potential (MMP) and percentage of apoptosis were determined by flow cytometry using Guava ${ }^{\circledR}$ EasyCyte $^{\mathrm{TM}}$ MitoPotential ${ }^{\mathrm{TM}}$ Kit (Cat. No. 4500-0250) consisting of 2 dyes JC1 and 7-amino actinomycin D (7AAD). For each treatment data was acquired for 5000 cells.

\section{Western blotting}

HeLa cells were seeded in 6 -well plates at 0.2 million cells per well in DMEM (containing 10\% FBS) and incubated in a humidified atmosphere of $5 \% \mathrm{CO}_{2}$ at $37^{\circ} \mathrm{C}$. After $24 \mathrm{~h}$ of incubation the cells were treated with $50 \mu \mathrm{M}$ of either of purified flavonoids or $100 \mu \mathrm{g}$ of crude methanolic extract for $24 \mathrm{~h}$. Cells were washed with $1 \mathrm{XPBS}$ and subsequently whole cell lysates were prepared in $150 \mu \mathrm{L}$ of $1 \times$ sample buffer (180 mM Tris-Cl pH 6.8, 6\% SDS, $15 \%$ glycerol, $7.5 \% \beta$-mercaptoethanol, and $0.01 \%$ bromophenol blue). Samples were immediately heated at $95^{\circ} \mathrm{C}$ for $3 \mathrm{~min}$. Equal volumes of samples were run on an SDS- $12 \%$ polyacrylamide gel and were transferred to nitrocellulose membrane by semidry transfer at $50 \mathrm{~mA}$ for $1 \mathrm{~h}$. Blots were probed with specific antibodies of Caspase 3 (1: 2000; IMG144A) and tubulin (as loading control) (1:5000; Sigma \#T5168) and stained with anti-mouse (Caspase 3) and antirabbit (tubulin) secondary antibody coupled with horseradish peroxidase (Sigma). Bands were visualized using an enhanced chemiluminescence protocol (Pierce) and radiographic film (Kodak). Developed radiographic film was scanned and band intensities were quantified using Image J software (www.imagej.en.softonic.com). 


\section{Statistical analysis}

Statistical significance was calculated between the untreated control cells Vs treatments. Data are presented as mean \pm standard error mean (SEM) and statistical analysis of data was performed by Unpaired-t test using graphpad software (www.graphpad.com).

\section{Acknowledgments}

Authors gratefully acknowledge financial support from the University Grants Commission, New Delhi and 12th FYP project (AARF, CSC0406) from CSIR, New Delhi, India. Thanks are due to Dr. Nishant S Jain, Chemical Biology Division, IICT, Hyderabad for providing the facility for SRB assay and western blotting. We express our thanks to Prof. T. Papi Reddy, Former Head, Department of Genetics, Osmania University for critical reading of the manuscript. NC and SRB thank UGC, New Delhi for providing research fellowship.

\section{Conflicts of Interest}

Authors declare there are no conflicts of interest.

\section{References}

[1] Fridlender M, Kapulnik Y, Koltai H. Plant derived substances with anti-cancer activity: from folklore to practice. Front Plant Sci 2015; 6: 799

[2] Chavan SS, Damale MG, Shamkuwar PB, Pawar DP. Traditional medicinal plants for anticancer activity. Int J Curr Pharm Res 2013; 5: 50-54

[3] Abhyankar G, Suprasanna P, Pandey BN, Mishra KP, Rao KV, Reddy VD. Hairy root extract of Phyllanthus amarus induces apoptotic cell death in human breast cancer cells. Innov Food Sci Emerg Technol 2010; 11: 526-532

[4] Cherukupalli N, Divate M, Mittapelli SR, Khareedu VR, Vudem DR. De novo assembly of leaf transcriptome in the medicinal plant Andrographis paniculata. Front Plant Sci 2016; 7: 1203

[5] Valdiani A, Talei D, Javanmard A, Tan SG, Kadir MA, Maziah M. Morpho-molecular analysis as a prognostic model for repulsive feedback of the medicinal plant "Andrographis paniculata" to allogamy. Gene 2014; 542: 156-167

[6] Luo W, Liu Y, Zhang J, Luo X, Lin C, Guo J. Andrographolide inhibits the activation of NF-KB and MMP-9 activity in $\mathrm{H} 3255$ lung cancer cells. Exp Ther Med 2013; 6: 743-746

[7] Mishra SK, Tripathi S, Shukla A, Oh SH, Kim HM. Andrographolide and analogues in cancer prevention. Front Biosci 2015; 7: 255-266

[8] Talei D, Valdiani A, Maziah M, Sagineedu SR, Saad MS. Analysis of the anticancer phytochemicals in Andrographis paniculata Nees. under salinity stress. Biomed Res Int 2013; 2013: 319047

[9] Sangameswaran B, Ilango K. Evaluation anti-hyperglycemic and anti-hyperlipidaemic activities of Andrographis lineata Nees on streptozotocin induced diabetic rats. Jordan J Biol Sci 2010; 3: 83-86

[10] Parlapally S, Cherukupalli N, Bhumireddy SR, Sripadi P, Anisetti R, Giri CC, Khareedu VR, Reddy VD. Chemical profiling and anti-psoriatic activity of methanolic extract of Andrographis nallamalayana J.L.Ellis. Nat Prod Res 2015; 8: 1-6

[11] Kandati V, Govardhan P, Reddy CS, Nath AR, Reddy RR. In-vitro and in-vivo anti-inflammatory activity of Andrographis serpyllifolia (Rottl. Ex Vahl.) Wt. Int Curr Pharm J 2012; 1: 199-204
[12] Neeraja C, Krishna PH, Reddy CS, Giri CC, Rao KV, Reddy VD. Distribution of Andrographis species in different districts of Andhra Pradesh. Proc Natl Acad Sci India Sect B Biol Sci 2015; 85: 601-606

[13] Gupta KK, Bharne SS, Rathinasamy K, Naik NR, Panda D. Dietary antioxidant curcumin inhibits microtubule assembly through tubulin binding. FEBS J 2006; 273: 5320-5332

[14] Jackson SJ, Murphy LL, Venema RC, Singletary KW, Young AJ. Curcumin binds tubulin, induces mitotic catastrophe, and impedes normal endothelial cell proliferation. Food Chem Toxicol 2013; 60: 431-438

[15] Arolla RG, Neeraja C, Rao KV, Reddy VD. DNA barcoding and haplotyping in different species of Andrographis. Biochem Syst Ecol 2015; 62: 91-97

[16] Martinez-Perez C, Ward C, Cook G, Mullen P, McPhail D, Harrison DJ. Langdon SP. Novel flavonoids as anti-cancer agents: Mechanisms of action and promise for their potential application in breast cancer. Biochem Soc Trans 2014; 42: 1017-1023

[17] Ravishankar D, Rajora AK, Greco F, Osborn HM. Flavonoids as prospective compounds for anti-cancer therapy. Int J Biochem Cell Biol 2013; 45: 2821-2831

[18] Selvendiran K, Koga H, Ueno T, Yoshida T, Maeyama M, Torimura T, Yano $\mathrm{H}$, Kojiro M, Sata M. Luteolin promotes degradation in signal transducer and activator of transcription 3 in human hepatoma cells: An implication for the antitumor potential of flavonoids. Cancer Res 2006; 66: 4826-4834

[19] Hodek P, Tepla M, Krizkova J, Sulc M, Stiborova M. Modulation of cytochrome P450 enzyme system by selected flavonoids. Neuro Endocrinol Lett 2009; 30: 67-71

[20] Mohammed A, Chiruvella KK, Rao YK, Geethangili M, Raghavan SC, Ghanta RG. In vitro production of echioidinin, 7-O-methywogonin from callus cultures of Andrographis lineata and their cytotoxicity on cancer cells. PLoS One 2015; 10: e0141154

[21] Vijayalakshmi A, Masilamani K, Nagarajan E, Ravichandiran V. In vitro antioxidant and anticancer activity of flavonoids from Cassia tora Linn. leaves against human breast carcinoma cell lines. Der Pharma Chemica 2015; 7: 122-129

[22] Guo X, Rukiya M, Mourboul A, Sheng L, Abulizi A. Anti-cancer activity of flavonoids from Xinjiang Glycyrrhiza inflata Licorice on proliferation, cytotoxicity and apoptosis in cervical carcinoma cells. J Med Plant Res 2013; 7: 173-188

[23] Park KI, Park HS, Nagappan A, Hong GE, Lee do H, Kang SR, Kim JA, Zhang J, Kim EH, Lee WS, Shin SC, HahYS Kim GS. Induction of the cell cycle arrest and apoptosis by flavonoids isolated from Korean Citrus aurantium L. in non-small-cell lung cancer cells. Food Chem 2012; 135: 2728-2735

[24] Yamaguchi M, Murata T, El-Rayes BF, Shoji M. The flavonoid p-hydroxycinnamic acid exhibits anticancer effects in human pancreatic cancer MIA PaCa-2 cells in vitro: Comparison with gemcitabine. Oncol Rep 2015; 34: 3304-3310

[25] Mojzis ], Varinska L, Mojzisova G, Kostova I, Mirossay L. Anti-angiogenic effects of flavonoids and chalcones. Pharmacol Res 2008; 57: 259-265

[26] Wang L, Wang J, Fang L, Zheng Z, Zhi D, Wang S, Li S, Ho CT, Zhao H. Anticancer activities of citrus peel polymethoxyflavones related to angiogenesis and others. Biomed Res Int 2014; 453972

[27] Elumalai N, Ayyakkannu P, Palanivelu S, Panchanadham S. In vitro antioxidant potential of Shemamruthaa (a herbal formulation) and its anticancer activity in the MCF-7 cell line. RSC Adv 2015; 5: 2312523133

[28] Carini JP, Klamt F, Bassani VL. Flavonoids from Achyrocline satureioides: Promising biomolecules for anticancer therapy. RSC Adv 2014; 4: 3131-3144

[29] Desagher S, Martinou JC. Mitochondria as the central control point of apoptosis. Trends Cell Biol 2000; 10: 369-377 
[30] Zamzami N, Susin SA, Marchetti P, Hirsch T, Gómez Monterrey I, Castedo M, Kroemer G. Mitochondrial control of nuclear apoptosis. J Exp Med 1996; 183: 1533-1544

[31] Li PD, Nijhawan D, Budihardjo I, Srinivasula SM, Ahmad M, Alnemri ES, Wang X. Cytochrome $c$ and dATP-dependent formation of Apaf-1/ caspase 9 complex initiates an apoptotic protease cascade. Cell 1997; 91: 479-489
[32] Green DR, Reed JC. Mitochondria and apoptosis. Science 1998; 281 : 1309-1312

[33] Shi Y. A structural view of mitochondria-mediated apoptosis. Nat Struct Biol 2001; 8: 394-401

[34] Mcllwain DR, Berger T, Mak TW. Caspase functions in cell death and disease. Cold Spring Harb Perspect Biol 2015; 7: a026716 